\title{
Building Undergraduates' Biological Capabilities through Reconstruction of Life-based Learning Curriculum
}

\author{
Hadi Suwono, Umie Lestari, Betty Lukiati, Sri Rahayu Lestari \\ Department of Biology, Faculty of Mathematics and Natural Sciences \\ Universitas Negeri Malang \\ Malang, Indonesia \\ hadi.suwono.fmipa@um.ac.id
}

\begin{abstract}
-21st century biological science is recommended to meet the people's needs in four key areas, namely sustainable food production, environmental protection, renewable energy, and human health improvisation. Indonesia is a country that is rich in biodiversity, as well as high levels of environmental susceptibilities especially species extinction and habitat destruction that lead to biodiversity declines. Biology is a branch of natural science that plays an important role in environmentally sustainable development. Biology is the basis of applied science such as medicine, pharmacy, agriculture including fisheries, animal husbandry, and forestry, which plays a role in poverty alleviation, prevents planetary destruction, and maintains the welfare of the world community. The life-based curriculum was developed to provide a framework for the development of a capable and excellent biology undergraduate. The undergraduate's capabilities include mastering competence as a biology researcher, spirituality, character, attitude, 21st century literacy, research capability, and self and organizational management. A graduate of biology undergraduate program is a biology scholar who has the spirit of Pancasila, entrepreneurship, cares about environmental preservation, and has the capability of a reliable biology researcher. As a biology researcher, a biology graduate can apply biological science to creating products (goods and/or services), literacy to technology and innovation, and create potentially useful biological discoveries. Research-based instruction in life-based learning provides students with an opportunity to engage in research and develop related skills such as critical thinking and problem-solving skills. Teaching and assessment methods are created to develop graduate capabilities in a sustainable manner.
\end{abstract}

Keywords-Biology undergraduate, Capability, Life-based Learning

\section{INTRODUCTION}

The 21st century is a knowledge era based on the advancement of biology [1]. Biology is a basic science that plays an important role in providing a foundation for the development of applied sciences that benefit the community. In the 21st century [2], biology is recommended to fulfill the community needs in four key areas, i.e. sustainable food production, environmental protection, renewable energy, and human health improvement. Currently, biology is rapidly advancing after the development of biotechnology. Today we have entered a great era, namely the era of biotechnology [3].

Globalization is currently determined by two forces, namely advances in information technology and biotechnology [4]. The era of 21st-century biotechnology is just as important as the advancement of information technology and computers. Biotechnology has become a boom, especially in agriculture and livestock, food industry, and healthcare industry. Biotech companies are currently racing against new drug discovery and drug development has reached over 300 drug products and 200 disease vaccines in the world including cancer, Alzheimer's, heart disease, AIDS, arthritis and other various infectious diseases. The development of other biotechnology that is still rapidly advancing is the genetic manipulation of plants and animals. Genetic engineering and GMO crops can be produced and be breakthroughs to develop plants that have super quality and able to result in massive production and are resistance to diseases caused by viruses, parasites, and are resistance to postharvest storage diseases.

Indonesia is a country with a high level of biodiversity, characterized by ecosystem and species diversities within the ecosystem, and germplasm (genetics) of each species [5]. Nevertheless, Indonesia is also a country with a high level of environmental vulnerability, especially the occurrence of species extinction and habitat destruction that causes declining biodiversity. Indonesia is one of the priority areas of world biodiversity conservation [6].

The progress of science and technology in Indonesia is enhanced to support the national development. According to the World Economic Forum (WEF), Indonesia's economic data show that Indonesia is still dependent on the utilization of natural resources (factor driven) and has not been generated from innovation (Innovation driven) [7]. Referring to the importance of biological positions in the development of Indonesia, the undergraduate biology program is expected to produce biologists who can respond to these challenges, which can utilize and add value to biodiversity by considering sustainability and conservation. 
In the United Nations Summit, the heads of UN member states agreed to adopt the Post-2015 Development agenda into an action plan to reduce human poverty, safe planetary degradation, and prosper the world community [8]. Indonesia, as a member of the United Nations, has agreed to an agenda called sustainable development. Sustainable development is in line with the definition made by the World Commission on Environment and Development (WCED), which is an effort to meet current needs without diminishing the ability of future generations to meet their needs. In order to achieve sustainable objectives, WCED requires fulfillment, increased production potential by environmental management and ensuring equal and equitable opportunity for all [6].

Sustainable development aims to improve the prosperity of the society, and to meet human needs and aspirations. Sustainable development is essentially aimed at finding the equitable distribution of intergenerational development both at present and in the future. According to UN (2015) development (which is basically more economic oriented), sustainability can be measured based on three criteria, namely: (1) no waste of the use of natural resources (depletion of natural resources); (2) no pollution and other environmental impacts; (3) its activities must be able to increase useable or replaceable resources. Ideally, a sustainable development requires an approach to achieving the sustainability or continuity of various aspects of life that include; ecology, economy, socio-culture, politics, and sustainable defense and security.

Biology is a branch of natural science that plays an important role in sustainable development that is environmentally sound. Biology is a basic science of applied science such as medicine, pharmacy, agriculture including fisheries, animal husbandry, forestry and so on, which supports human poverty reduction, prevents planetary destruction, and prospers the world community.

A reconstruction of undergraduate biology curriculum is expected to educate students who have the worker competencies for the 21 st century. The world of work requires not only academic / technical merits, but also nonacademic [9]. Such non-academic skills are also called soft skills, which are needed in the 21 st century. Soft skill is a "micro social" skill categorized into intrapersonal and interpersonal skills, personal and social skills, and cognitive skills [9]. According to Metiri Group and NCRL [10], competencies possessed by the 21 st century generation include academic skills, thinking skills, reasoning skill, cooperation, and using technology to drive agility. Partnership in the 21 st Century Skills categorizes 21 st century skills into three general skills, namely 1) information and communication; 2) thinking and problem solving; and 3) interpersonal and self-organizing skills. In another reference, Partnership for the 21 st Century Skills in collaboration with The National Science Teachers Association (NSTA) describes the 21 st century skills as skills that need to be learned by students in the context of science education (NEA, 2014). The 21 st century working skills are creativity and innovation, critical thinking and problem solving, as well as literacy skills i.e. communication, collaboration, information literacy, media literacy, information and communication technology literacy, flexible and adaptive, having initiative and self-directed, social, cross-cultural, productive and accountable, and leadership and responsibility [11]. The working skills of the 21 st century must be mastered by undergraduate biology students who will become biologists.

The curriculum is the framework that forms the foundation for the planning of learning experiences and learning activities, which is programmed and organized by educational institutions that help learners to achieve educational goals. The National Standard of Higher Education (SN-DIKTI) in Article 1 states that a curriculum is a set of plans and arrangements regarding graduates' learning achievements, study materials, processes, and assessments used as guidelines for the implementation of the study programs. According to Pinar, a curriculum is a number of activities and learning experiences experienced by learners, which are organized and directed by educational institutions so that graduates obtain the knowledge, attitudes, and skills that have been established [12]. The current curriculum is developed by taking into account the holistic, multidisciplinary, social, historical, and ecological dimensions [13].

The assumption that higher education is a producer of labors results in lectures that only focus on learning to work [14]. This causes the learning process to be limited to work training activities. The concept of life-based learning suggests that learning to work involves different cognitive, affective, and psychomotoric aspects needed in the work world of the 21 st century. As stated by [15], "Life-based learning proposes that learning for work is not restricted to learning at work". Life-based learning or life wide learning focuses on learning by involving all aspects of human life at every stage of time and the utilization of various learning resources. Learning is a multi-dimensional experience, adults gain experience during work. Therefore, the development of their professions affects their way of thinking and working [15].

The world of work requires not only academic/technical skills, but also non-academic skills. Such non-academic skills are also called as soft skills. The concept is developed in the undergraduate biology program. Life-based learning provides learning experiences in various aspects of human beings, whether developing hard skills or soft skills. Life-based learning makes use of a variety of learning resources that open the opportunities for developing learners' abilities and potentials.

The current biological curriculum development is in line with current research development that is complementing traditional biological research with the advanced biological research that solves human needs for sustainable food production, environmental protection, renewable energy and human health [16]. In other words, the biological curriculum is developed via a transdisciplinary approach to solving human problems (Figure 1). It is therefore appropriate that biology graduate education uses transdiciplinary life-based curriculum. Transdisciplinary is a term used to describe interdisciplinary linkages in contributing to the scope/area of research. Interdisciplinary integrates various disciplines into a form of a hierarchical disciplinary, cross-disciplinary, multidisciplinary, interdisciplinary and transdisciplinary [17]. 


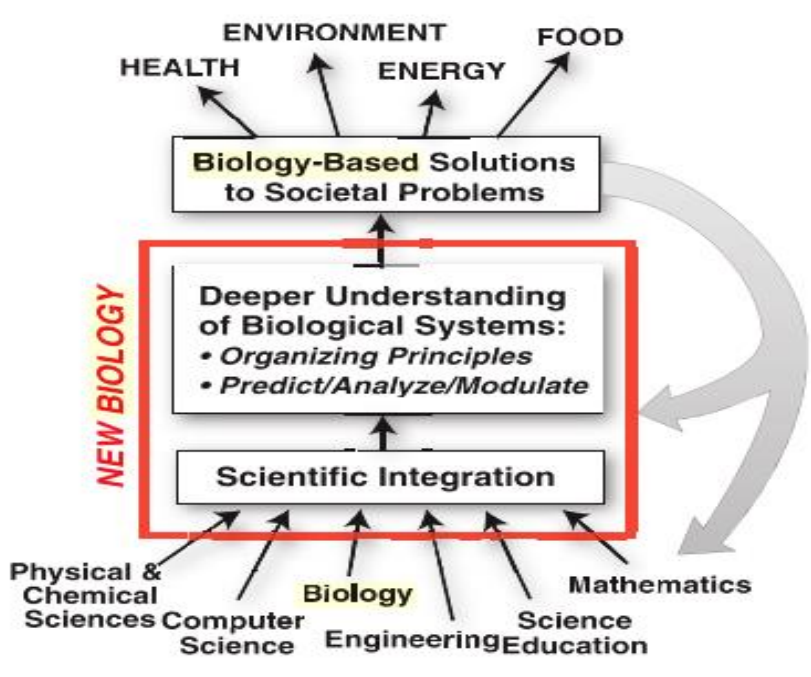

Fig. 1. New biology integrates knowledge of various disciplines to gain more understanding of biological systems to solve social problems [16]

Multidiscipline implies an issue being reviewed / examined from several disciplines without being integrated. Interdisciplinary is an integration of several disciplines to solve problems. Trans disciplinary is a problem solving solution through the integration of several disciplines that can create a new understanding (synthesis).

Development of undergraduate biology curriculum includes the formulations of graduate profile, learning outcome, and curriculum structure including learning strategy and its assessment. The development of life-based curriculum is intended for graduates of biology department having the capabilities of the 21 st century work world so as to compete and achieve in the world of work. The skills of the working world of the 21 st century are creativity and innovation, critical thinking and problem solving, as well as literacy capabilities to communicate, collaborate, and have information literacy, media literacy, literacy on information and communication technology literacy, flexible and adaptive, initiative and selfdirected, cross-cultural, productive and accountable social skills, as well as leadership and responsibility.

\section{METHODS}

To develop a curriculum design that will be used by the faculties and / or departments of biology in Indonesia, we involve biology lecture at every step of the process. We use a bottom-up approach developed by Brownell et.al [18], which involves members of the biology faculty who are involved the education committee and / or engaged in biological education research.

\section{A. Phase I. Development and Review of the Internal Curriculum}

Firstly, we get input from the faculty members of the Biology Department of Malang State University. In particular, we involve faculty members by asking them to consider whether the main concepts of Vision and Change in
Undergraduate Biology Education, A Call to Action [19] and the Biological Curriculum Framework of KOBI (the Biology Consortium of Indonesian) are important to be understood by graduates of biology majors. Through focus group discussions, we found a strong alignment between the goals in Vision and Change and the Biological Curriculum Framework of KOBI in the form of a pre-defined curriculum framework for biology department objectives.

\section{B. Phase II. Review and Validation}

In the second phase of the curriculum development, we asked for feedback about the initial draft from biology professors with different sub disciplinary expertise in biology from various national institutions. We ask them to evaluate each statement and provide feedback on the accuracy and the importance of undergraduates' capability to graduate from biology department.

\section{RESULTS AND DISCUSSION}

\section{A. Graduate Profile of Biology Program}

The biology study program is designed to support a sustainable development. Therefore, it is necessary to develop the management of the study program from the aspect of tridharma (three teachings) that leads to innovation, creativity and applied biology for the needs of society. The curriculum of biology is aimed at developing capabilities that are tailored to students' lives both today and in the future (life-based learning). The objectives of undergraduate biology program is to motivate students to be biological researchers, who have Pancasila spirits, possess entrepreneurship ability, are able to solve health, food, energy, environmental, and biodiversity conservational problems. Such major theme is chosen based on the following reasons: 1) biodiversity is the basic capital to improve public health so it has to be utilized, empowered and conserved, 2) food, health, and energy have become both national and international issues; 3) biodiversity can be empowered to solve the problem of food availability and supporters of health program, 4) it is necessary to make efforts of sustainable utilization of biodiversity and its preservation.

A graduate of biology study program is a biology researcher with the following scopes of research:

- Discover new concepts in the field of biology to enrich biology as a basic science.

- Discover new concepts that bridge the development of basic biology, applied biology and industry

- Identify, discover, utilize, and manipulate biological agents that support the research in the fields of food and health.

- Develop the results of basic biological research and apply them to products of goods or services that can be utilized by the community. 


\section{B. The Learning Outcome of Undergraduate Biology Program}

The higher education curriculum should ensure that its graduates have the qualifications which are equivalent to the Indonesian National Qualification Framework (KKNI). In KKNI, the formulation of students' competences is expressed in terms of learning outcomes. Learning outcome contains of four elements, namely attitudes and values, work ability, scientific knowledge mastery, and authority and responsibility. From the element of knowledge mastery, biology department students must understand biological system that unifies the molecular and cellular level, which controls the type, performance, and which can be inherited. This variation leads to an extraordinary variety of organisms. In order for biology students to understand this feature, concepts must be taught in various contexts. They should also consider whether to incorporate the concepts of chemistry, physics, and mathematics that help and underlie the idea into biology lectures. Biology students introduce true interdisciplinary concepts of biology.

Biological science studies the organizational systems of living things that include studies of the structure, process, diversity and sustainability of the system. According to the Indonesian Biological Consortium (KOBI), biological science is a study about (1) cell and molecular biology, (2) physiology or a study of processes occurring in living things' systems, (3) genetics, i.e. a study about the substance of genes and their inheritance processes to ensure the survival of living systems, (4) structure and development, which examine individual organization and ontogenetic changes of organization, (5) biosystematics and evolution that studies the diversity of living things and its phylogenetic history, and (6) ecology, which studies individual organizations based on population, community, and ecosystem to biosphere levels. The six areas of study are then referred to as biological scales.

Woodin et al. agreed that all undergraduate biology students should develop understanding of the 5 core concepts namely evolutionary biology; structure and function of organisms; information flow, exchange, and storage; pathways and transformations of energy and matter; and systems [19]. On the other hand, a biology undergraduate is also required to master the competence of applying the science process; to use quantitative reasoning skill; to use modeling and simulation; to utilize the interdisciplinary nature of science; to communicate and collaborate with other disciplines; and to understand the relationship between science and society. Biology students are also expected to apply biological knowledge in the management and utilization of biological resources by using technology in the fields of food, health, and the environment to support sustainable development.

Graduates of biology programs are also designed to have a strong spirituality and nationality. The expected characters from a biology program graduate include showing devotion to the omnipotent God and demonstrating religious attitudes, understanding and applying the national characters based on Pancasila, and possessing the attitudes and behaviors that care for the preservation of biodiversity.
TABLE I. EXPECTED LEARNING OUTCOME FROM A BIOLOGY GRADUATE

\begin{tabular}{|c|c|}
\hline Feature Capability & Description \\
\hline Basic Science & $\begin{array}{l}\text { Understanding the basic science that underlie } \\
\text { scientific thinking in biological field }\end{array}$ \\
\hline $\begin{array}{l}\text { Body knowledge of } \\
\text { biology }\end{array}$ & $\begin{array}{l}\text { Mastering biological knowledge, including cell } \\
\text { biology, biodiversity, structure and function, } \\
\text { genetics, evolution, and ecology }\end{array}$ \\
\hline Applied biology & $\begin{array}{l}\text { Applying biological knowledge in the management } \\
\text { and utilization of biological resources by using } \\
\text { technology in the field of food, health, and } \\
\text { environment to support sustainable development }\end{array}$ \\
\hline Spirituality & $\begin{array}{l}\text { show a great devotion to the omnipotent God and } \\
\text { show religious attitudes }\end{array}$ \\
\hline Character & $\begin{array}{l}\text { Understand and apply the national characters based } \\
\text { on Pancasila }\end{array}$ \\
\hline Attitudes & Care for the conservation of biodiversity \\
\hline $21^{\text {st }}$ literacy & $\begin{array}{l}\text { Mastering the } 21^{\text {st }} \text { century literacy: } \\
\text { a) life and career skills; } \\
\text { b) } 4 \text { 'Cs: Critical thinking, communication, } \\
\text { collaboration, creativity } \\
\text { c) Information, media, and technology literate }\end{array}$ \\
\hline Skills & $\begin{array}{l}\text { Master the skill of using the software and hardware } \\
\text { used in scientific works in the biological field }\end{array}$ \\
\hline Research capability & $\begin{array}{l}\text { a) Understand and apply scientific methods } \\
\text { through discoveries and testing hypotheses; } \\
\text { b) Internalize academic values, norms and ethics; } \\
\text { c) Be able to find and analyze biological problems } \\
\text { and formulate solutions through research } \\
\text { including analysis of statistical data in making } \\
\text { conclusions }\end{array}$ \\
\hline $\begin{array}{l}\text { Self and institutional } \\
\text { management }\end{array}$ & $\begin{array}{l}\text { Responsible for the work and can be responsible for } \\
\text { the organizational achievement for the work }\end{array}$ \\
\hline
\end{tabular}

The skills developed in the 21st century include life and career skills that is also called as 4 Cs i.e., critical thinking, communication, collaboration, creativity; information, media, and technological literacy. The learning outcomes of the undergraduate biology programs have been established based on the capability analysis (Table 1).

\section{Student Centered Learning: Research-based Instruction}

All undergraduate students should experience learning through, and about, research and inquiries [20]. It will be possible if the experiences are integrated into the curriculum [21]. Fernate et al. stated that research-based learning will provide students with the opportunity to develop researchrelated capabilities such as critical thinking and problem solving [22]. Poonpan and Suwanmankha also explained that research-based learning will develop students' inquiry skills so that students do not only have the opportunity to acquire knowledge of the content, but also to learn skills such as searching, hypothesizing, collecting data, testing data or analyzing data, and summarizing data [23]. Such skills are called research abilities. The above explanation shows that information that is based on students' research will make the students understand the scientific facts and concepts and have an understanding of how to work scientifically [24]. Based on his research, Wannapiroon explained that research-based learning can improve the competence of graduates' research and critical thinking abilities consisting of principles, objectives, learning process, and evaluation [25].

Various efforts have been made to integrate research into learning such as by enriching teaching materials with some 
findings from the latest research and tracking the history of the latest discoveries, enriching learning activities with contemporary research issues, teaching research methodologies, supplementing the learning process with smallscale research activities, improving the learning process by involving students in institutional research activities, enriching the learning process by encouraging students to take part of the research culture in their faculty/department, and enriching learning process with the values that must be owned by researchers. Furthermore, Umar et al. explained that there are several interpretations of research-based learning, among others [26]; (1) learning by using research results as lecture materials; (2) lecturing activities in the form of research such as data collection, data exposure, conclusion, and so on; and (3) lecturing activities supported by sufficient learning resources with adequate ICT support. Learning using several RBL models can be developed according to the characteristics of the scientific study as well as the condition of the facilities available in such unit of education.

Research-based learning is a learning system that promotes authentic learning, problem solving, cooperative learning, contextual learning, and the use of inquiry-discovery teaching approach based on three learning theories guided by the philosophy of constructivism [23], [25], [27]. Poonpan and Suwanmankha explained that research-based learning is intrigued by three learning theories that include (1) behaviorism [23]: providing the foundation that research learning can be strengthened; (2) cognitivist: this theory believes that receiving new information and storing data while trying to understand the meaning of the information, and (3) constructivism: students build new knowledge through developing their previous understanding, learning from social interactions, and learning from real experiences to result in a meaningful learning. The purposes of research-based learning at the university level are as follows.

- Narrow the gap between research and academic contents through a research-based approach by creating an environment that includes important integration of research activities into learning [22].

- Change students' learning methods and encourage them to practice on learning by doing as well as using a scientific knowledge acquisition tool that provides opportunities for students not only to learn concepts but also to practice research-related skills, such as building and testing hypotheses, collecting and analyzing data or checking data, and making conclusions [23], [25], [28].

- Help students to develop special knowledge, improve multidisciplinary competences, research methodologies, and ability to ask and solve problems [28].

- Introduce the concepts and tools of scientists, make it possible for students to understand the research process, and carry out instructions and document the scientific knowledge that is generated and transferred into the application context [22].

- Increase learning achievement in the form of higher order thinking level (critical thinking) and capabilities related to research or investigation (research ability) [22], [23], [25], [29].

Research-based instructions facilitate students to learn to link between a subject and research [29]. The relationship between teaching and research can be developed in four models and each model is in the form of a learning strategy that can be seen in Table 2.1. Poonpan and Suwanmankha explained that research-based learning is divided into two, namely [23]: (1) based on its type, it is divided into learning with the content of research findings and teaching methods, and learning by the process of building knowledge by searching, establishing hypotheses, collecting data, analyzing data, and making inferences from the new data or new lessons; (2) based on its nature, it is divided into reviews of research as the content of the lesson and the development of research process as a tool in the investigation of learning.

Griffiths first formulated research and teaching relationships in three approaches namely 'research-led', 'research-oriented' and 'research-based' learning models [29]. Healey and Jenkins added 'research-tutored' as the fourth curriculum model [21]. The four approaches are distinguished by the focus of the research (i.e. process versus content) and the role of the student as (i.e. students as active-participants versus students as audience). In research-led approach, students learn about the latest research findings. The curriculum is structured on the subject content and linked to recent research advances. The application of research-led model requires the teacher to voluntarily integrate the latest research findings generated by other researchers into his or her teaching program. The second approach or research-oriented learning requires students to learn about the research process. The curriculum emphasizes the understanding of the processes and skills of inquiry and research. The third model or the researchtutored learning involves students in research discussions. Such learning model focuses on students and faculty who should critically discuss research in many disciplines such as, for example, in many seminar-based courses. The fourth approach or research-based learning requires students to study as researchers. The curriculum designed for inquiry activities, not for understanding learning contents. The teaching emphasizes a more balanced cooperation between lecturers and students. Table 2 embodies the study-based learning models and strategies. 
TABLE II. STUDENT-CENTERED LEARNING STRATEGY FOR DEVELOPING RESEARCH CAPABILITY

\begin{tabular}{|c|c|c|c|}
\hline $\begin{array}{c}\text { Level of } \\
\text { student }\end{array}$ & $\begin{array}{c}\text { Research } \\
\text { engagement }\end{array}$ & $\begin{array}{l}\text { Research } \\
\text { approach }\end{array}$ & Description learning process \\
\hline I & Basic skill & $\begin{array}{l}\text { Research- } \\
\text { led }\end{array}$ & $\begin{array}{l}\text { Learn about research outside the } \\
\text { research setting } \\
\text { Develop basic technical skills in } \\
\text { research } \\
\text { Use current research as teaching } \\
\text { materials } \\
\text { Involve students as part of the } \\
\text { research culture }\end{array}$ \\
\hline II & $\begin{array}{l}\text { Research } \\
\text { skill }\end{array}$ & $\begin{array}{l}\text { Research } \\
\text { oriented }\end{array}$ & $\begin{array}{l}\text { Moderate intellectual engagement in } \\
\text { research } \\
\text { Teach research methods } \\
\text { Join a research team and assume } \\
\text { responsibility for part of an ongoing } \\
\text { research project under the guidance } \\
\text { of a mentor } \\
\text { Develop technical research skills } \\
\text { Learn data management practices } \\
\text { and analytical skills } \\
\text { Construct explanations or develop } \\
\text { arguments based on evidence } \\
\text { Embed the values of a researcher }\end{array}$ \\
\hline III & $\begin{array}{l}\text { Research } \\
\text { experience }\end{array}$ & $\begin{array}{l}\text { Research } \\
\text { oriented, } \\
\text { Research } \\
\text { tutored }\end{array}$ & $\begin{array}{l}\text { Extensive intellectual engagement } \\
\text { in research } \\
\text { Involve students in research } \\
\text { discussions } \\
\text { Improve learning activities with } \\
\text { current research issues } \\
\text { Participate in a research team } \\
\text { community and practice by } \\
\text { attending team meetings, journal } \\
\text { clubs, and so on. } \\
\text { Assume the responsibility for an } \\
\text { independent research project from } \\
\text { thebeginning to end } \\
\text { Review, evaluate, and integrate } \\
\text { findings from the primary literature } \\
\text { to draw and interpret the results of } \\
\text { the project } \\
\text { Conduct research under the } \\
\text { guidance of a mentor and make } \\
\text { decisions to adjust or change the } \\
\text { direction of the project when } \\
\text { necessary } \\
\text { Analyze data, draw conclusions, and } \\
\text { communicate research findings } \\
\text { verbally or in writing to the research } \\
\text { team } \\
\text { Define directions for future studies } \\
\text { based on research results }\end{array}$ \\
\hline IV & $\begin{array}{l}\text { Research } \\
\text { program }\end{array}$ & $\begin{array}{l}\text { Research- } \\
\text { based }\end{array}$ & $\begin{array}{l}\text { Extensive intellectual engagement } \\
\text { in research and professional } \\
\text { development } \\
\text { Develop contextual understanding } \\
\text { through peer review by } \\
\text { communicating research findings } \\
\text { beyond the immediate research } \\
\text { community of practice } \\
\text { Build a research professional } \\
\text { network by socializing into the } \\
\text { culture of research beyond the } \\
\text { immediate research community of } \\
\text { practice } \\
\text { Explore research careers } \\
\text { Develop research identity through } \\
\text { guided reflection and self- } \\
\text { evaluation }\end{array}$ \\
\hline
\end{tabular}

The current biological curriculum requires reconstruction for various reasons. Biology has evolved into a wide range of sub disciplines and applications including by playing a role in solving social, food, health, energy, and environmental problems [16]. The exponential development of biological discovery makes it difficult to decide what to include in a 4year undergraduate curriculum [18].

We cannot teach students about everything in biology and a consensus of the most important matters to teach is necessary [18]. The exponential development of biological sciences requires a dynamic teaching process. The core concept and competence proposed by Woodin [19] have become an important foundation in the development of biology undergraduate curriculum. The National Research Council explained that in addition to teaching concepts, biologists recognize that future biologists, and indeed all future workers and citizens, also require more general skills such as reading, writing, critical thinking, and communication skills [16]. These skills are needed as a foundation in, for example, writing research grant proposals and writing research results. Such types of activities also provide an opportunity for students to consider the connection between scientific discoveries and the community, including the importance of scientific methods and scientific ethics. To meet these challenges, we cannot rely solely on teaching on topics covered through lectures and guided laboratory sessions/prescriptions, i.e., an approach that can be counterproductive and can often leave students with misconceptions and, perhaps, negative impression. Instead, we all need to rethink about our teaching contents - such as which historically important thing in biology that we should include, which key of research is being done today, and which implications that a graduate might have in the future while meeting the different needs of students.

The biology department prepares students to master the new biology of the 21 st century. For such purpose, faculty members should develop to be more effective teachers and encourage all students to develop the ability to think critically, be able to evaluate evidence and to argue. Undergraduates of biology can graduate, at a minimum, with a basic understanding of the core principles of biology and core competencies of biology. Improving the teaching ability of biology faculty members can also help the biology faculty develop courses that involve all students.

Over the past decade, innovators in science education research have been exploring new models of science teaching and curriculum design, as well as examining teaching from a scientific perspective [30]. The teaching of biology is contextual and embedded by the way of scientific thinking carried out by experts [31], which provides an opportunity for students to be actively involved in finding the scientific concepts of scientific phenomena in everyday life through inquiry [32]. "Scientific teaching" recommends that learners study biology through how science is acquired including developing defined concepts and competencies. The teaching of biology begins with the articulation of clear and measurable learning objectives, followed by the application of appropriate assessment tools to evaluate the extent to which students have achieved this goal. 
The teaching of biology was developed based on students centered learning (SCL). SCL is a learning approach that places students as a learning center that determines content, activities, learning materials, and learning speed. Instructors provide students with the opportunities to learn effectively with self-driven ideas, motivations, and goals. It also involves the process of collaboration with other teachers or learners [33]. Although the definition of student-centered learning may vary, many experts agree that student-centered learning reveals interaction among students, encourages inquiry, fosters cooperative and collaborative work, and effectively achieves learning goals. This includes solving complex biological issues that require activities to identify questions/problems, hypothesize, collect data, analyze data, and formulate scientific explanations of the solutions [34], [35].

Inquiry-based teaching and investigation have been widely publicized as the foundation for biology learning [34], including building students' research skills [36]. Inquiry focuses on describing, explaining, predicting, and communicating scientific phenomena and guiding students to seek for information, explore, solve problems and discover new insights [37]. Inquiry is an effective strategy in helping students to understand concepts and foster science process skills [38]. Inquiry results provide a valuable context for learners to acquire and clarify the concept of science through active research, and apply an understanding of the concept in daily practice. Results prove that inquiry increases students' interest in learning science, stimulates motivation [39], and also improves their learning outcomes [40]. Some researchers have investigated the impact of inquiry on the understanding of biological concepts [40]. The results of research conducted by Chabalengula and Mumba showed that students gain a better understanding of biological knowledge about the heart and blood vessel system and students achieve higher test scores after using inquiry-based instruction [41]. The results of a study conducted by Hickey et al. who were cited by HmeloSilver, Duncan, and Chinn [42], showed significantly greater gains from the pretest to posttest than student acquisition in control classes.

Research-based teaching has been used by biologists to improve student-solving skills and to inform further research on problem solving in biology [35]. The involvement of undergraduate biology students in handling research also enhances their scientific thinking. Research activities that are integrated into teaching allow students to experience the authentic activities of working scientists, including designing research, interpreting results, considering alternative approaches, and testing new techniques.

\section{CONCLUSION}

Based on the new direction of the biological science development, curriculum policies need to develop biological education and to ensure that all graduates develop biological literacy. Biology scholars need to understand, contribute, and make decisions about the complex problems that the world is facing. The new challenges are the development of a life-based curriculum as well as the practice and teaching of biology that develop capabilities by integrating content mastery, attitudes, character, values, managerial skills, and research. The "research teaching" and "scientific classroom" development areas provide input for biology researchers and biology educators to work together to build student-centered learning.

\section{ACKNOWLEDGEMENT}

The research on curriculum development in biology undergraduate program was sponsored by the Grant from the Islamic Development Bank.

\section{REFERENCES}

[1] C. R. Woese, "A new biology for a new century," Microbiol. Mol. Biol. Rev., vol. 68, no. 2, pp. 173-186, 2004.

[2] A. C. Janetos, "A New Biology for the 21st Century," Front. Ecol. Environ., vol. 7, no. 9, p. 455, 2009.

[3] H. Van den Belt, A. Jansen, F. Keulartz, F. Valkema, and C. Van der Weele, "Global change and biotechnology," Comm. Genet. Modif. Rep. CGM 2008, vol. 6, 2008.

[4] S. Effendi, "Pengelolaan Perguruan Tinggi Menghadapi Tantangan Global," in Seminar Nasional Majelis Rektor Indonesia, 2003.

[5] A. B. Setyowati et al., "Pokja Kebijakan Konservasi," in Konservasi Indonesia: Sebuah Potret Pengelolaan dan Kebijakan, Jakarta: Perpustakaan Nasional, 2008.

[6] Suhartini, "Suhartini. (2009). Peran Konservasi Keanekaragaman Hayati Dalam Menunjang Pembangunan Yang Berkelanjutan," in Prosiding Seminar Nasional Penelitian, Pendidikan Dan Penerapan MIPA, 2009, pp. 199-205.

[7] RISTEKDIKTI, "Rencana Strategis 2015-2019," Direktorat Jenderal Penguatan Riset dan Pengembangan, 2015. .

[8] U. Nations, "Transforming our world: the 2030 Agenda for Sustainable Development," SUSTAINABLE DEVELOPMENT KNOWLEDGE PLATFORM, 2015. .

[9] V. Babić and M. Slavković, "Soft and hard skills development: a current situation in Serbian companies," in Proceedings of the Management, Knowledge and Learning International Conference, 2011.

[10] NCREL and M. Group, "enGauge ${ }^{\circledR}$ 21st Century Skills FOR 21ST CENTURY LEARNERS,” 2003.

[11] National Education Association, Preparing 21 st Century Students for a Global Society: An Educator 's Guide to the "Four Cs ." 2014.

[12] W. F. Pinar, What is Curriculum Theory? Mahwah, New Jersey: Lawrence Erlabaum Associates, 2004.

[13] P. Slattery, Curriculum Development In the Postmodern Era. New York: Routledge, Taylor \& Francis Group, 2006.

[14] V. D'Andrea and D. Gosling, Improving Teaching And Learning In Higher Education: A Whole Institution Approach: A Whole Institution Approach. London: McGraw-Hill Education (UK), 2005.

[15] M. Staron, M. Jasinski, and R. Weatherley, "Life Based Learning: A strength based approach for capability development in vocational and technical education," 2006.

[16] N. R. Council, Desalination: a national perspective. Washington, DC: National Academies Press, 2008.

[17] P. Stock and R. J. Burton, "Defining terms for integrated (multi-intertrans-disciplinary) sustainability research," Sustainability, vol. 3, no. 8, pp. 1090-1113, 2011.

[18] S. E. Brownell, S. Freeman, M. P. Wenderoth, and A. J. Crowe, "BioCore Guide: a tool for interpreting the core concepts of Vision and Change for biology majors," CBE-Life Sci. Educ., vol. 13, no. 2, pp. 200-211, 2014.

[19] T. Woodin, V. C. Carter, and L. Fletcher, "Vision and change in biology undergraduate education, a call for action-initial responses," CBE-Life Sci. Educ., vol. 9, no. 2, pp. 71-73, 2010. 
[20] M. Jenkins and M. Healey, "Developing and Embedding InquiryGuided Learning Across an Institution.," New Dir. Teach. Learn., vol. 2012, no. 129, pp. 27-37, 2012.

[21] M. Healey and A. Jenkins, "Developing undergraduate research and inquiry," Heslington, 2009.

[22] A. Fernate, S. Surikova, D. Kalmina, and C. S. Romero, "ResearchBased Academic Studies: Promotion of the Quality of Learning Outcomes in Higher Education?," in European Conference on Educational Research, 2009.

[23] S. Poonpan and S. Suwanmankha, "Indicators of Research - Based Learning Instructional Process:A Case Study of Best Practice in a Primary School," in AARE Annual Conference, 2005.

[24] S. Altun-Yalçln, S. AçıŞlı, and Ü. Turgut, "Determining the levels of pre-service science teachers' scientific literacy and investigating effectuality of the education faculties about developing scientific literacy," Procedia-Social Behav. Sci., vol. 15, pp. 783-787, 2011.

[25] P. Wannapiroon, "Development of research-based blended learning model to enhance graduate students' research competency and critical thinking skills," Procedia-Social Behav. Sci., vol. 136, pp. 486-490, 2014.

[26] M. K. Umar, M. Yusuf, Supartin, R. Uloli, T. Abjul, and N. E. NtobuO, "Pengembangan Pembelajaran Berbasis Riset Di Program Studi Pendidikan Fisika Fmipa Universitas Negeri Gorontalo," Gorontalo, 2011.

[27] D. T. Widayati et al., "Pedoman Umum Pembelajaran Berbasis Riset (PUPBR)," Yogyakarta, 2010.

[28] Katrin Klink M.A., “Guidelines: Research-oriented Teaching Definition and Possibilities of Implementation at KIT," 2015.

[29] R. Griffiths, "Knowledge production and the research--teaching nexus: The case of the built environment disciplines," Stud. High. Educ., vol. 29, no. 6, pp. 709-726, 2004.

[30] J. B. Labov, S. R. Singer, M. D. George, H. A. Schweingruber, and M. L. Hilton, "Effective practices in undergraduate STEM education part 1: examining the evidence," CBE-Life Sci. Educ., vol. 8, no. 3, pp. 157-161, 2009.

[31] M. Braund, J. Benneth, G. Main, and G. Hampden-thompson, "Teaching approach and success in A-level Biology," 2013.

[32] K. Tanner and D. Allen, "Approaches to biology teaching and learning: understanding the wrong answers - teaching toward conceptual change," Cell Biol. Educ., vol. 4, no. 2, pp. 112-117, 2005.
[33] S. Mckendry and V. Boyd, "Defining the "Independent Learner' in UK Higher Education: Staff and Students' Understanding of the Concept," Int. J. Teach. Learn. High. Educ., vol. 24, no. 2, pp. 209-220, 2012.

[34] I. Karsai and G. Kampis, "The crossroads between biology and mathematics: The scientific method as the basics of scientific literacy," Bioscience, vol. 60, no. 8, pp. 632-638, 2010.

[35] A.-M. Hoskinson, M. D. Caballero, and J. K. Knight, "How can we improve problem solving in undergraduate biology? Applying lessons from 30 years of physics education research," CBE-Life Sci. Educ., vol. 12, no. 2, pp. 153-161, 2013.

[36] R. Vartak, A. Ronad, and V. Ghanekar, "Enzyme assay: an investigative approach to enhance science process skills," J. Biol. Educ., vol. 47, no. 4, pp. 253-257, 2013.

[37] Y. T. G. Mei, C. Kaling, C. S. Xinyi, J. S. K. Sing, and K. N. S. Khoon, "Promoting science process skills and the relevance of science through science ALIVE! programme," Proc. Redesigning Pedagog. Cult. Knowladge Underst. Conf. Singapore. Environ. Sci. Educ., vol. 3, no. 1, pp. 30-34, 2007.

[38] H. Akcay and R. E. Yager, "Students Learning to Use the Skills Used by Practicing Scientists," Eurasia J. Math. Sci. \\& Technol. Educ., vol. 12, no. 3, pp. 513-525, 2016.

[39] E. Trna, Josef and Trnova, "The current paradigms of science education and their expected impact on curriculum," Procedia-Social Behav. Sci., vol. 197, pp. 271-277, 2015.

[40] G. N. Cervetti, J. Barber, R. Dorph, P. D. Pearson, and P. G. Goldschmidt, "The impact of an integrated approach to science and literacy in elementary school classrooms," J. Res. Sci. Teach., vol. 49, no. 5, pp. 631-658, 2012.

[41] V. M. Chabalengula, F. Mumba, T. Lorsbach, and C. Moore, "Curriculum and Instructional Validity of the Scientific Literacy Themes Covered in Zambian High School Biology Curriculum," Int. J. Environ. Sci. Educ., vol. 3, no. 4, pp. 207-220, 2008.

[42] C. E. Hmelo-Silver, R. G. Duncan, and C. A. Chinn, "Scaffolding and achievement in problem-based and inquiry learning: A response to Kirschner, Sweller, and Clark (2006)," Educ. Psychol., vol. 42, no. 2, pp. 99-107, 2007. 